\title{
Acceleration of Telemedicine Use for Chronic Neurological Disease Patients during COVID-19 Pandemic in Yogyakarta, Indonesia: A Case Series Study
}

\author{
Rizaldy Pinzon ${ }^{1,2}$, Dessy Paramitha ${ }^{1,2}$, Vincent Ongko Wijaya ${ }^{1,2 *}$
}

${ }^{1}$ Neurology Department, Bethesda Hospital, Yogyakarta, Indonesia

2Faculty of Medicine, Duta Wacana University, Yogyakarta, Indonesia

\begin{abstract}
COVID-19 preventions have cut access to routine medical care, especially for many chronic neurological disease patients. This condition has especially promoted telemedicine use in providing healthcare. This study aimed to review telemedicine use catalyzed by several regulations of the Indonesian Government and review 20 cases from Bethesda Hospital in Yogyakarta providing online consultation services. Perceptions of experience on telemedicine were collected from neurological patients at the hospital who were asked about their impressions of consultations and pharmacy medication services, and their suggestions about the new system in outpatient consultations. The regulations for telemedicine use are relevant because of these patients' risks related to comorbidities and treatments. Of the 20 respondents involved in this study, $15(75 \%)$ were satisfied with the service, $3(15 \%)$ very satisfied, and $2(10 \%)$ others neutral. Most respondents suggest improvement of reimbursement (80\%) and others suggest improvement on medications (10\%) and services (10\%). System and hospital requirements for telemedicine services for neurological cases have been accelerated due to the pandemic. Telemedicine is a way to provide healthcare needed by patients at high risks for COVID-19 fatality related to comorbidities and treatments. Payment regulations, regulatory structures, state licensing, and credentialing across hospitals for better telemedicine experience need to be enhanced.
\end{abstract}

Keywords: COVID-19, Indonesia, neurologic disorder, telemedicine

\section{Introduction}

In December 2019, a cluster of pneumonia cases occurred on Wuhan, China. The World Health Organization (WHO) has officially named the disease as coronavirus disease 2019 (COVID-19) and it has become a major health problem worldwide. 1,2 Data on May 2, 2020 , showed that there were 10,843 positive cases in Indonesia, with a mortality rate reaching $831(7.7 \%)$ cases. ${ }^{3}$ A review study has estimated the basic reproduction number (R0) of SARS-CoV-2 to be around 2.2. 4

Social distancing and quarantine have cut off access to routine medical care for many chronic neurological disease patients. Patients with the chronic neurological disease have some poor prognostic factors for COVID19 fatality, for example, advanced age (alzheimer and parkinson) or vascular risk factors (stroke). ${ }^{5}$ Data from Indonesia show that most of the fatal cases have been related to these risks (hypertension, diabetes, and cardiovascular / stroke condition). ${ }^{3}$

The Indonesian Government has already launched the

Correspondence*: Vincent Ongko Wijaya, School of Medicine, Duta Wacana University, Wahidin Sudirohusodo Street 5-25, Yogyakarta, Indonesia, 55284, Email: vincent_wijaya007@yahoo.com, Phone: +62-813-9274-5050
Regulation on the Health Informatics and Telemedicine System in 2014.6 With the Indonesian Medical Council (IMC), or Komisi Kedokteran Indonesia (KKI), they have also launched another regulation dealing with the COVID-19 crisis. ${ }^{7,8,9}$ This regulation states that patients with high risks should avoid traditional outpatient visits if possible, especially in crowded hospitals. The current COVID-19 crisis has accelerated the use of telemedicine for caring for these patients, especially with many comorbid and advanced age. This study aimed to review the acceleration of telemedicine use catalyzed by the government regulations, as well as to review 20 cases from Bethesda Hospital in Yogyakarta, Indonesia, which provides online consultation services.

\section{Method}

This study was a cross-sectional study using a questionnaire-based measurement to evaluate the satisfaction of telemedicine use during the COVID-19 pandemic. It collects the current regulations of the Indonesian Government and medical association on 
Table 1. Regulations from the Indonesian Government and Medical Associations

\begin{tabular}{|c|c|c|c|}
\hline Regulation & Date & Scope & Requirement \\
\hline The Ministry of Health $(303 / 2020)$ & April 29, 2020 & Inpatient and outpatients setting & $\begin{array}{l}\text { Electronic prescribing and electronic } \\
\text { medical record }\end{array}$ \\
\hline $\begin{array}{l}\text { Indonesian Medical Council (IMC), or } \\
\text { Komisi Kedokteran Indonesia (KKI), } \\
(74 / 2020)\end{array}$ & April 29, 2020 & $\begin{array}{l}\text { Non-emergency cases should use } \\
\text { telemedicine } \\
\text { Outpatients setting }\end{array}$ & $\begin{array}{l}\text { Electronic prescribing and electronic } \\
\text { medical record }\end{array}$ \\
\hline $\begin{array}{l}\text { The Indonesian Food and Drug Authority } \\
\text { (FDA) }(8 / 2020)\end{array}$ & April 2020 & $\begin{array}{l}\text { Medicine, food supplement, and tradi- } \\
\text { tional medicine } \\
\text { Exception: opioid analgesic, tranquilizer }\end{array}$ & $\begin{array}{l}\text { Electronic prescribing and electronic } \\
\text { medical record }\end{array}$ \\
\hline $\begin{array}{l}\text { The Indonesian Neurological Association } \\
\text { (INA) }(032 / 2020)\end{array}$ & April 2020 & $\begin{array}{l}\text { Mild cases, over the counter medication, } \\
\text { symptomatic treatment }\end{array}$ & None \\
\hline
\end{tabular}

telemedicine and COVID-19 as shown in Table 1. It also collects case series from Bethesda Hospital in Yogyakarta from neurological patients who used telemedicine (video call by application for outpatient consultation). The patient survey was undertaken after consents were obtained following video-call outpatient consultations. The subjects were asked about their perceptions of the consultation, the service of medication on pharmacy, and their suggestions about the new system in outpatient consultation. ${ }^{10}$ Their responses were noted in self-made questionnaires designed for this study. The system and hospital requirements for telemedicine services for neurological cases were also reviewed in this study. This study has obtained ethical permission from the Bethesda Hospital Research and Development Department. Oral informed consent had been taken from the subjects before the survey was conducted.

\section{Results}

As a response to the COVID-19 crisis in Indonesia, the Indonesian Government has launched the Regulation of Ministry of Health on the use of telemedicine (Table 1). The Indonesian Neurological Association (INA) also responded to this situation. ${ }^{11}$

These regulations are very suitable for patients with neurological diseases because of these patients' conditions (advanced age), risk factors (hypertension and diabetes), and treatments (immunosuppressive for multiple sclerosis or myasthenia gravis). Most of these regulations require electronic prescribing and electronic medical records for the use of telemedicine consultations. The prescriptions of controlled substances such as analgesics or opioids require legitimate medical purposes in accordance with the law.

Outpatient visits for neurological disease during the COVID-19 pandemic are inefficient and often unsafe. Individuals may require long travels to hospitals, wherein sparsely populated areas it may take hours for them. Following long commutes, patients often sit in crowded waiting rooms and pharmacies. This study reviews 20 cases that have already used online consultation and the
Table 2. The Characteristics of the 20 Patients Using Online Consultations at Bethesda Hospital Neurological Outpatient Clinics on April 2020

\begin{tabular}{llrr}
\hline Characteristic & Category & Total & $\%$ \\
\hline Sex & Male & 14 & $70 \%$ \\
Age & Female & 6 & $30 \%$ \\
Diagnosis & $<60$ years old & 2 & $10 \%$ \\
& $\geq 60$ years old & 18 & $90 \%$ \\
& Stroke & 12 & $60 \%$ \\
& Parkinson & 2 & $10 \%$ \\
Level of satisfaction & Vertigo & 2 & $10 \%$ \\
with the services & Back pain & 1 & $5 \%$ \\
& Other & 3 & $15 \%$ \\
& Very satisfied & 3 & $15 \%$ \\
\multirow{3}{*}{ Suggestions from patients } & Neither satisfied or not & 15 & $75 \%$ \\
& Not satisfied & 2 & $10 \%$ \\
& Reimbursement & 0 & 0 \\
& Medication & 16 & 0 \\
& Services & 2 & $10 \%$ \\
& & 2 & $10 \%$ \\
\hline
\end{tabular}

demographic data is shown in Table 2. Most of the subjects are male $(70 \%), \geq 60$ years old $(90 \%)$ and have been diagnosed with stroke $(60 \%)$. More than $75 \%$ of the subjects were satisfied with the use of telemedicine for their chronic neurological consultation. In terms of suggestion, $80 \%$ of the subjects suggest the reimbursement services be evaluated during the COVID-19 pandemic for their consultations.

\section{Discussion}

The COVID-19 pandemic has resulted in unprecedented disruptions in health care and hospital services. It has not only been affecting the COVID-19 patients, but also patients with chronic neurological cases. ${ }^{12,13}$ The significant impact of the COVID-19 pandemic on the healthcare system and the rapid depletion of its resources, urgent steps should be taken while managing acute stroke patients to prevent the spread of the disease, to protect both patients and staff, and to minimize the uses of already strained resources.

The strict emphasis on self-isolation and social distancing has become the main factor that raises serious concerns about the well-being of patients with chronic 
neurological diseases, given these patients require routine hospital visits for evaluation and medical adjustments. ${ }^{14}$

More than $75 \%$ of the subjects in our study were satisfied with the use of telemedicine for their online consultations. These results may become a reference for some hospitals that some patients and caregivers can cope with the larger use of telemedicine for health care services. A previous study has already shown the potential for using telemedicine in disasters and public health emergencies. 15

The rapid responses from the Indonesian Government and $K K I$ on the potential use of telemedicine have been responded by professionals and specialty associations. The regulation cannot be responded to immediately by every hospital because of the limitations on electronic medical records and electronic prescribing system. A previous study has shown that there is great disparity among health care facilities and hospitals in Indonesia. ${ }^{16}$

Our study on 20 cases with chronic neurological disease patients was promising. Most respondents showed a positive response to the new outpatient consultation method. Most of our patients are older than 60 years old and disabled due to their illness (stroke). Therefore, the video calls online consultations were established by the providers to avoid travel to in-person care sites. This study only focused on doctor-patient consultation. In stroke care, much additional care should be in place. The majority of the important works done by dietary consultants, pharmacists, and stroke education nurses could potentially be done without direct patient contact in many cases. The challenges will be in the physical therapy and rehabilitation aspects. ${ }^{13}$

Most of our subjects $(80 \%)$ suggested the reimbursement method be recalculated because of the differences between direct consultation and telemedicine in terms of physical examination and communication. A past study of telemedicine and reimbursement for vascular surgery consultation was significant to the patients. The use of telemedicine provided an increase in reimbursement from private payers and acceptance from patients, which ranged from $0 \%$ to $67 \%$ of the total charges billed. However, telemedicine use has proven to be effective to reach a broader population base, and without significant cost to the patients. ${ }^{17}$

The use of telemedicine, especially online consultation, has been growing very slowly in Indonesia. Face to face consultations has become the main method of outpatient visits. This study shows that the system, hospital system, and regulations have been accelerated due to the COVID-19 pandemic. For the neurological disease patients, these conditions are relevant because of their risks related to the comorbidities and treatments.

The American Academy of Neurology describes the limitations of telemedicine especially in the terms of neurological examination including comprehensive eye exams, neuromuscular components, and vestibular examinations. ${ }^{17}$ The main barriers to maintaining this telemedicine are related to the reimbursement system. This approach can only be conducted in private patients and limited for patients managed under the national health insurance program. The payers for the national health insurance system and other private insurances company should modify their payment policy in response to COVID-19. The limitations of our study are that there are no follow-ups for the long term and clinical outcomes, as well as the measurement methods of the subjects' satisfaction, which are based on self-made questionnaires. Therefore, the validity and reliability of the instrument have yet to be tested.

\section{Conclusion}

The COVID-19 pandemic has presented unique challenges to hospital and patients care. The significant impact of the pandemic on the healthcare system in Indonesia has called for urgent steps for managing chronic neurological patients. The use of telemedicine is required to prevent the spread of the disease, protect both patients and staff, and minimize the uses of already strained resources. Payment and regulatory structures, state licensing, credentialing across hospitals should be modified as the response to this.

\begin{abstract}
Abbreviations
WHO: World Health Organization; COVID-19: Coronavirus Disease 2019; IMC: Indonesian Medical Council; KKI: Komisi Kedokteran Indonesia; INA: Indonesian Neurological Association.
\end{abstract}

Ethics Approval and Consent to Participate

This study has been approved by the Health Ethics Committee of Bethesda Hospital.

\section{Competing Interest}

The authors declare no conflict of interest to disclose.

\section{Availability of Data and Materials}

The data and materials of this study were available upon request to the first author.

\section{Authors' Contribution}

Rizaldy Pinzon: Study concept and design, writing of the initial draft, supervision, data availability; Dessy Paramitha: Methodology, writing and revision of the manuscript; Vincent Ongko Wijaya: Data analysis, writing and revision of the manuscript.

\section{Acknowledgment}

Not Applicable 


\section{References}

1. Lu R, Zhao X, Li J, Niu P, Yang B, Wu H, et al. Genomic characterization and epidemiology of 2019 novel coronavirus: implications for virus origins and receptor binding. Lancet. 2020; 395 (10224): 565-74.

2. World Health Organization. Coronavirus disease (COVID-2019) situation reports; 2020.

3. Indonesian Task Force for COVID-19. Current situation reports of COVID-19 in Indonesia; 2020.

4. Liu Y, Gayle AA, Wilder-Smith A, Rocklov J. The reproductive number of COVID-19 is higher compared to SARS coronavirus. Journal of Travel Medicine. 2020; 27 (2).

5. Peraturan Pemerintah Nomor 46 Tahun 2014 tentang Sistem Informasi Kesehatan (Lembaran negara Republik Indonesia Tahun 2014 Nomor 126, Tambahan Lembaran Negara Republik Indonesia Nomor 5542). Republik Indonesia.

6. Indonesian Ministry of Health regulation, 303/2020, Indonesian Health Ministry regulation of the use of Information Technology and Communication for Preventing the COVID-19, Indonesian Ministry of Health.

7. Indonesian Medical Council Regulation, 74/2020, The Use of Telemedicine and clinical appointment in the Era of COVID-19 Pandemic. Indonesian Medical Council.

8. Indonesia FDA regulation, 8/2020. Indonesia FDA regulation for medicine and food online transaction, Indonesia FDA 2020.
9. Al-Abri R, Al-Balushi A. Patient satisfaction survey as a tool towards quality improvement. Oman Medical Journal. 2014; 29 (1): 3-7.

10. Indonesian Neurological Association. Technical information for the use of telemedicine for neurological patients. Indonesia: Indonesian Neurological Association; 2020.

11. Helmich RC, Bloem BR. The impact of the COVID-19 pandemic on parkinson's disease: hidden sorrows and emerging opportunities. Journal of Parkinsons Disease. 2020; 10 (2): 351-4.

12. Dafer RM, Osteraas ND, Biller J. Acute stroke care in the coronavirus disease 2019 pandemic. Journal of Stroke and Cerebrovascular Diseases. 2020; 29(7): 104881.

13. Bloem BR, Dorsey ER, Okun MS. The coronavirus disease 2019 crisis as catalyst for telemedicine for chronic neurological disorders. JAMA Neurol. Published online April 24, 2020. doi:10.1001/jamaneurol.2020.1452

14. Lurie N, Carr BG. The role of telehealth in the medical response to disasters. JAMA Intern Med 2018; 178: 745-6.

15. Mulyanto J, Kringos DS, Kunst AE. The evolution of income-related inequalities in healthcare utilisation in Indonesia, 1993-2014. PLoS ONE. 2019; 14(6): e0218519.

16. Lin JC, Kavousi Y, Sullivan B, Stevens C. Analysis of outpatient telemedicine reimbursement in an integrated healthcare system. Annals of Vascular Surgery. 2020; 65: 100-6.

17. Evans DA, Benameur K, Busis N. Telemedicine and COVID-19. American Academy of Neurology. 2020 [Accessed May 27, 2020]. 